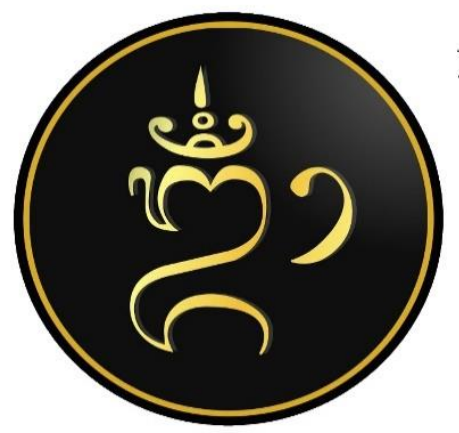

E-ISSN: 2722-8576

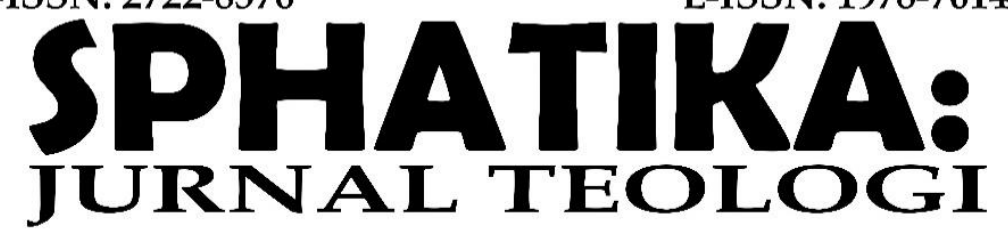

UNIVERSITAS HINDU NEGERI

I GUSTI BAGUS SUGRIWA DENPASAR

VOLUME 12 NOMOR 2, SEPTEMBER 2021

\title{
IMPLEMENTASI MITOLOGI DAN SIMBOL GANESHA DALAM BUDAYA KONTEMPORER MASYARAKAT BALI
}

\author{
Agus Sumarpin Giri' ${ }^{1}$ I Gede Suwantana ${ }^{2}$ \\ 1,2Universitas Hindu Negeri I Gusti Bagus Sugriwa Denpasar \\ 1agus.marvin@yahoo.com
}

\begin{tabular}{l}
\hline Keywords: \\
contemporary \\
culture; ganesha; \\
implementation \\
\hline
\end{tabular}

Kata kunci:

budaya

kontemporer;

Ganesha;

implementasi

\begin{abstract}
Culture and mythological narratives about Ganesha are inherent in the life of the Hindu community in Bali, but have undergone various changes along with the pace of civilization. Evidently, Ganesha as one of the sacred symbols is widely used in various life interests of modern society, which has no relevance to the sacred context. This paper analyzes the implementation of Ganesha's symbolic mythology in the contemporary cultural space of Balinese society. Mythologically, Ganesha is believed to be the son of Shiva who has the power to overcome all obstacles. This mythology is contained in the attributes of Ganesha which have a symbolic meaning. The full embodiment of the Ganesha symbol in the modern era is widely implemented in the contemporary culture of Balinese life, both in the fields of architecture, aesthetics (art), social organization, including economic life. This work is expected to be a reference for fostering a critical and selective culture when using the Ganesha symbol in various aspects of Balinese life.
\end{abstract}

\begin{tabular}{l} 
Abstrak \\
\hline Budaya dan narasi mitologi mengenai Ganesha melekat dalam \\
kehidupan masyarakat Hindu di Bali, namun mengalami \\
berbagai perubahan seiring dengan laju peradaban. Terbukti, \\
Ganesha sebagai salah satu simbol suci banyak difungsikan \\
dalam berbagai kepentingan hidup masyarakat modern, yang \\
tidak memiliki relevansi dengan konteks sakral. Tulisan ini \\
menganalisis implementasi mitologi simbolik Ganesha dalam \\
ruang budaya kontemporer masyarakat Bali. Secara mitologis, \\
Ganesha lebih banyak dipercayai sebagai putra Siva yang \\
memiliki kekuatan menupas segala halangan. Mitologi ini \\
tertuang dalam atribut Ganesha yang memiliki arti simbolik. \\
Perwujudan utuh dari simbol Ganesha di era modern banyak \\
diimplementasikan dalam budaya kehidupan kontemporer
\end{tabular}


masyarakat Bali baik dalam bidang arsitektur, estetika (kesenian), organisasi sosial, termasuk kehidupan ekonomi. Karya ini diharapkan dapat menjadi referensi untuk menumbuhkan budaya kritis dan selektif ketika menggunakan simbol Ganesha dalam berbagai aspek kehidupan masyarakat Bali.

\section{PENDAHULUAN}

Ekistensi manusia sebagai mahluk yang memiliki kepekaan atas asas budaya, secara langsung mendorong manusia itu sendiri untuk melakukan berbagai bentuk upaya penerimaan, terhadap segala hal yang berkaitan dengan produk-produk kebudayaan. Produk kebudayaan baik yang terwujud secara fisik ataupun yang masih terealisasi dalam satuan tatanan nilai, akan dipandang sebagai sebuh unsur vital, begitu juga memiliki asas fundamental yang harus mendapatkan perhatian, pelestarian termasuk upaya regenerasi dari keberadaan budaya itu sendiri.

Lahirnya dorongan untuk melakukan upaya pelestarian terhadap produk kebudayaan, dipicu oleh beberapa hal secara mendasar. Terkait dengan hal tersebut maka Kumbara (2008 : 203) berasumsi bahwa pelestarian kebudayaan semata-mata terlahir dari bisikan bhatin dari individu baik dalam kesengajaan ataupun tanpa sadar, selalu berupaya untuk menghayati dan mempelajari kebudayaan yang hidup dalam masyarakat tempat dia lahir dan berkembang, sehingga secara langsung ataupun tidak langsung individu itu sendiri akan bertindak sebagai pendukung kebudayaan yang bersangkutan Oleh sebab itu, produk kebudayaan yang kini dapat disimak baik melalui artefak, kesenian, organisasi, sistem sosial dan wujud budaya dalam bentuk lainnya, masih berdiri kokoh meskipun selalu mendapatkan berbagai bentuk pengaruh baik secara ekternal maupun internal yang mencoba memberikan guncangan terhadap kebudayaan. Tidak menutup kemungkinan hal tersebut juga berlaku terhadap aspek budaya dalam konteks irasional, yang salah satunya terealisasi dalam cakupan pemikiran bersifat mitologis yang nantinya terwujud dalam sebuah fenomenologi simbolik.

Unsur mitologi simbolik banyak diterapkan oleh manusia didalam menguraikan tentang beberapa hal disekitarnya, yang tidak memiliki kepastian dari sisi historikal, bersifat misteri dan irasional, akan tetapi memiliki wujud atau bukti yang dapat dipandang memiliki tingkat relevansi tinggi dengan mitologi itu sendiri. Disisi lain, aspek mitologi dan simbolik juga diaplikasikan untuk mempercayai kekuatan bersifat transcendental yang cenderung atau notabene terdapat dalam kehidupan beragama umat manusia. Mitologi simbolik dalam 
lingkup religius secara umum memiliki fungsi sebagai media untuk memperkuat keyakinan umat terhadap eksistensi Tuhannya.

Agama Hindu merupakan salah satu faham religius di Bali, yang memiliki kekayaan dalam aspek tradisi dan budaya religi. Pelestarian begitu juga pelaksanaan tradisi keagamaan yang terjadi di dalamnya, juga tidak dapat terlepas dari kontribusi historis mitologis yang nantinya diimplementasikan kedalam berbagai bentuk kontruksi simbol dengan kekayaan dan kedalaman makna filosofis. Kentalnya realitas simbolik yang terlahir dari keyakinan mitologis, cenderung menjadi dasar bagi agama Hindu dikatakan sebagai agama simbol. Kedudukan simbol dalam Hindu, pada beberapa aspek dapat memberikan adanya kemajuan pola fikir dan tindakan dari umat sesuai dengan maksud dan makna intrinsic yang terdapat dalam simbol itu sendiri. Hal tersebut dipertegas kembali dengan asumsi Keramas (2008: 6) yang menyatakan bahwa konsepsi simbol dalam agama Hindu, akan menyadarkan umat atau manusia Hindu Bali tentang idea dan cita-cita. Antara mitologis dan simbolisme dalam Hindu, akan terkolaborasi dan terwujud dalam berbagai hal seperti, sarana Kultus, kesenian sakral, termasuk artefak berupa Arca atau patung yang sering fungsikan sebagai objek sentral dalam memusatkan konsentrasi pemujaan.

Pemujaan terhadap patung atau Arca merupakan perwujudan Tuhan dalam Hindu yang dituangkan dalam aspek Saguna Brahman (Tuhan yang berpribadi). Keberadaan Arca dan patung itu sendiri akan lebih banyak mengambil wujud atau bentuk tertentu sesuai dengan mitologi fungsional dari Tuhan (Ida Shang Hyang Widhi Wasa), baik sebagai sumber pengetahuan, penguasa kesejahteraan dan kemakmuran, kesuburan, termasuk fungsi Tuhan sebagai penghalang segala halangan (Awigna Gna) yang dalam hal ini disimboliskan dengan Arca Dewa Ganesha.

Ganesha berkedudukan sebagai manifestasi (Ida Sang Hyang Widhi) sebagai Dewa yang memiliki kekuatan untuk menumpas segala bentuk halang rintangan. Secara umum Ganesha mengambil perwujudan manusia bekepala gajah, memiliki empat tangan begitu juga dilengkapi dengan beberapa kelengkapan atribut. Ganesha merupakan salah satu kontruksi simbolisme bernuansa hinduistik yang dipandang serta dipercaya memiliki kesucian dan berperan untuk menumpas segala halangan yang ditemui manusia.

Namun, berkembangnya budaya kontemporer memberikan wajah baru bagi posisi dan kepercayaan terhadap Ganesha. Secara mendasar, budaya kontemporer dapat didefinisikaan sebagai kondisi budaya yang banyak terpengaruh oleh modernisme atau situasi terkini dari dunia. Hal ini berpijak pada definisi dari budaya dan kontemporer itu sendiri. Budaya adalah segala hal atau bentuk baik berwujud benda maupun berkenaan 
dengan sistem non-benda, yang dihasilkan oleh manusia dalam skala individu atau kelompok dan didasarkan pada kemampuan, akal, ide, dan gagasannya (Mutakin, 2006: 78). Sementara itu, kontemporer memiliki arti pada waktu atau masa yang sama atau pada masa kini (KBBI, 2008: 805). Berdasarkan arti kata tersebut, maka budaya kontemporer merujuk pada kondisi budaya yang sedang berlaku saat ini. Oleh sebab itu, Piliang (2011: 209) mengistilahkan budaya kontemporer sebagai budaya global. Budaya kontemporer adalah segala hal yang dihasilkan manusia baik berwujud ataupun tidak, yang berasal dari kemampuan akal, ide, atau gagasan pada masa kini. Meminjam pendapat Setyaningrum (2002: 229) maka dapat dikatakan bahwa, budaya yang mudah terpengaruh oleh modernisasi atau perkembangan masa kini disebabkan oleh sifat cair (Fluid) pada budaya. Budaya global atau kontemporer tersebut, menjelaskan tentang mendunianya berbagai aspek kebudayaan dalam ruang global yang ditujukkan oleh terjadinya proses penyatuan, saling berkaitan dan saling berhubungan. Kondisi ini sangat tepat, mengingat posisi budaya pada saat ini ada dalam posisi yang sangat rentan yang disebabkan oleh adanya imperialisme budaya dalam berbagai bidang dan menyebabkan tergerusnya budaya lokal. Budaya lokal sebagai identitas yang dimiliki oleh seseorang menjadi semu maknanya, ketika dihimpit oleh modernisasi. Identitas dalam diri seseorang menjadi hilang ketika imperialisme kebudayaan modern semakin merebak.

Ganesha sebagai simbol sakral dan identitas lokal Hindu di Bali dihadapkan pada realitas semu di era budaya kontemporer saat ini. Kondisi ini terlihat dari perbedaan implementasi Ganesha di era agraris (masa lampau) dan perhelatan modern saat ini. Ketika Hindu Bali masih diselimuti dengan budaya klasik bernuansa agraris, maka penggunaan simbol Ganesha baik dalam bentuk patung (Arca) maupun media lukis (Rerajahan) hanya tertuju pada situasi, tempat dan acara ritualisme tertentu. Bahkan Ardani (2017: 373) mejelaskan bahwa, di beberapa tempat Ganesha memiliki nilai mendalam baik dalam konteks Tattwa, sosio-religius, dan estetika. Akan tetapi memasuki "era nano" yang kental dengan budaya kontemporer saat ini, unsur keindahan dan keagungan dari Ganesha digunakan sebagai salah satu komposisi objek, baik dengan tujuan meningkatkan keserasian dan keindahan dalam ruang, seni ornament dan lukisan baik yang tertuang dalam kanfas hingga tato pada tubuh, simbolis dan lambang pada satuan organisasi tertentu, termasuk difungsikan sebagai label sebuah prodak ekonomi. Mitologi dan simbol Ganesha yang kini merasuk dalam pusaran arus budaya kontemporer, tentunya dapat menimbulkan berbagai problematika yang secara khusus menyasar kehidupan bergama Hindu, sebagai faham religi pemilik mitologi simbolik Ganesha. Salah satu permasalahan yang mungkin akan dihadapi 
adalah munculnya asumsi yang mempertanyakan realitas Hindu apakah sebagai penghormat atau bahkan penghujat simbol keagamaan sendiri.

\section{METODE}

Kajian penelitian ini merupakan penelitian kualitatif yang menggunakan pendekatan teologi. Teknik pengumpulan data menggunakan teknik studi kepustakaan yang diperoleh melalui pustaka suci Hindu. Teknik analisis data menggunakan teknik reduksi data, tahap penyajian data (display) dan tahap penarikan kesimpulan (verifikasi).

\section{PEMBAHASAN}

\section{Selayang Pandang Hakikat Mitologi Dan Simbol}

Istilah mitologi apabila disimak dalam Kamus Besar Bahasa Indonesia (2001), memiliki pengertian sebagai sebuah klasifikasi ilmu dalam ranah pengetahuan sastra yang memiliki kandungan konsepsi dan dongeng suci mengenai kehidupan Dewa dan mahluk halus dalam suatu kebudayaan. Sementara itu Putra (2009: 1) lebih mengkonsepsikan istilah mitologi sebagai untaian kisah suci yang menguraikan tentang terbentuknya alam semesta, dunia ataupun manusia sebagaimana realitas yang dapat dilihat saat ini. Disisi lain juga terdapat beberapa asumsi secara mendasar, yang mengatakan bahwa mitologi adalah pengetahuan terkit dengan mitos. Mengacu pada beberapa pengertian dan pendapat yang menjelaskan tentang konsep mitologi diatas, maka secara umum dapat disimpulkan bahwa mitologi merupakan sebuah pengetahuan yang didalamnya mengupas begitu juga mendeskripsikan tentang ceritra bersifat irasional, bernuansa magis yang nantinya dipercaya keberadaannya sebagai sebuah pemahaman dan uraian filosofis pada sebuah kehidupan budaya masyarakat.

Sebagaimana kedudukan mitologi diatas, maka simbol juga memiliki pengertian atau penjabaran konsepsiologis tersendiri. Secara etimologi (Symbol) berasal dari bahasa Yunani yakni dari kata "Sym-bellein" yang memiliki arti melemparkan bersama suatu (benda, perbuatan) dikaitkan dengan suatu ide (Hartoko \& Rahmanto, 1998: 133). Sarjana lainnya seperti Herusatoto (2000 : 10) berpendapat bahwa simbol (Symbol) merupakan tanda, lambang atau ciri yang berusaha untuk menyampaikan serta memberitahukan sesuatu pesan kepada seseorang. Berpijak pada deskripsi pengertian simbol diatas, maka dapat ditarik sebuah pemahaman bahwa simbol merupakan sesuatu yang dipergunakan untuk menunjukkan sesuatu dari sesuatu lainnya, baik berupa kata-kata (pesan Verbal), prilaku non Verbal serta objek yang maknanya telah dipahami serta disepakati secara bersama. 
Pada beberapa lingkungan kehidupan budaya, kedudukan antara mitologi dengan sebuah simbol terlihat memiliki tingkat kesesuaian dan relevansi yang sangat erat. Meskipun hakikat sebuah mitologi selalu diwarnai dengan nuansa yang bertentangan dengan pemikiran secara rasionalistik, akan tetapi pada beberapa aspek hal tersebut dapat ditepis melalui bukti nyata yang nantinya dapat disimak melalui sebuah kontruksi simbol. Gambaran tersebut dapat disimak dalam penerapan dan pengejawantahan sebuah faham keagamaan tertentu dengan tujuan akhir untuk memperkuat sebuah tatanan kehidupan beragama.

Agama Hindu sebagai sebuah faham keagamaan dengan konsep luhur dan pemaknaan filosofis, cenderung memposisikan kedudukan antara mitologi dan simbol sebagai dua aspek yang saling memiliki keterkaitan. Mitologi dan simbol nantinya akan diintegrasikan yang selanjutnya difungsikan untuk mempekuat sisi keyakinan (Srada) umat didalam melakukan pendekatan kehadapan Ida Shang Hyang Widhi Wasa, serta memahami segenap nilai dan ajaran luhur dalam agama Hindu itu sendiri. Realita simbol sebagai pengejawantahan akhir dari pola fikir simbolis manusia Hindu terhadap sebuah mitologi, juga menjadi salah satu indikasi adanya pandangan maju dari manusia Hindu itu sendiri. Sebab sebagaimana asumsi Ernst Cassirer (1987) dalam Dharmayuda (1995: 2) yang menyatakan bahwa seluruh kemajuan manusia didasari oleh kemampuan berfikir secara simbolis, yang merupakan karakteristik atau ciri khas murni dari kondisi manusiawi.

\section{Mitologi Ganesha}

Cerita mitologis terakait dengan keberadaan Ganesha dapat ditemukan dalam beberapa dokumentasi tertulis. Masing-masing refrensi yang mengulas tentang keberadaan Ganesha memberikan adanya deskripsi yang beragam terkait dengan sejarah kelahiran, perjalanan kehidupan begitu juga jasa-jasa yang dilakukan oleh Ganesha. Apabila mengacu pada untian ceritra yang diakui secara universal maka dapat dideskripsikan bahwa Ganesha adalah putra Sang Hyang Siva yang berwujud Devata dengan badan menyerupai manusia berkepala gajah. Sang Hyang Siva menunjuk dewa Ganapati atau Ganesha sebagai pemimpin para Gana, yakni pengikut Sang Hyang Siva, oleh karenanya Dewa ini dinamakan Ganapati atau Ganadipa.

Namum sumber lainnya seperti Linga Purana (Rao, 1968 : 35 dalam Titib, 2009 : 276), menyebutkan bahwa Ganesha diciptakan oleh Siva atas permintaan dewa Indra dan para dewa lainnya. Suatu ketika para dewa diserang pasukan asura dan raksasa yang mempunyai kekuatan tidak terkalahkan atas anugrah Siva. Pada suatu ketika Siva yang mendapat 
pemujaan dari Asura sedemikian khusuknya, merasa senang sehingga ia mengabulkan permintaan asura agar menjadi makhluk yang tidak terkalahka. Asura menjadi sombong dan bermaksud menguasai sorga tempat tinggal para dewa. Para Dewa yang mendapat serangan bala tentara Asura dan raksasa tidak sanggup membendung serangan mereka. Untuk menghalanginya mereka meminta bantuan Siva. Berduyun-duyun para Dewa menghadap Siva memohon agar diciptakan suatu makhluk yang dapat menandingi kekuatan asura guna merintangi serangan mereka. Siva kemudian menyerahkan satu dari amsa-nya, yang merupakan sebagian kekuatannya dalam bentuk seorang pemuda tampan yang lahir dari rahim Parvati. Parvati sangat bangga melihat ketampanan putranya. Pemuda tersebut dinamakan Vighnesvara oleh Siva, dan diperintahkan untuk menghalangi dan mengalahkan para asura dan raksasa. Diantara para Dewa, ada seorang yang tidak mau memandang Vighnesvara, yakni Sani (Saturnus), karena sedang terkena kutukan istrinya, apapun yang ditatap oleh Sani akan berubah menjadi abu. Parvati mengatakan bahwa itu tidak akan terjadi pada putranya, maka dengan berat hati Sani menatap Vighnesvara. Namun yang terjadi di luar perhitungan, kepala pemuda itu hancur menjadi abu. Brahma kemudian menghibur Parvati dengan janji bahwa kepala binatang yang pertama kali ditemukan setelah peristiwa itu akan menyelamatkan putranya. Visnu yang sedang naik garuda menemukan seekor gajah, lalu memenggal kepalanya dan memasangkannya ke leher Vighnesvara. Kemudian ia dinamakan Ganesha.

Versi berbeda terkait kelahiran Ganesha, juga dapat disimak dalam Kitab Matsya Purana dan Skanda Purana (Rao, 1968: 41; Getty, 1971 : 5 dalam Titib, 2009 : 277) yang menceritrakan bahwa kelahiran Ganesha dalam wujud manusia berkepala gajah, pada masa antara Dvaparayuga dan Kalkiyuga, para wanita, kaum sudra, serta para pembuat dosa mendapat kesempatan masuk ke kahyangan dengan cara melakukan Tirthayatra ke pura Somesvara. Indra memohon kepada Siva agar merintangi mereka. Siva tidak dapat menarik kembali atas anugrah yang telah diberikannya. Siva menyarankan untuk meminta belas kasihan Parvati. Para Dewa kemudian memohon belas kasihan Parvati dengan mempersembahkan puji-pujian kehadapan sang Dewi. Parvati merasa senang atas persembahan para Dewa, dan mengabulkan permintaan mereka. Kemudian ia menggosokkan tubuhnya. Tiba-tiba muncul makhluk bertangan empat, berkepala gajah. Parvati menyebutnya sebagai Ganapati, kekasih Siddhi dan Buddhi, Ganesha dan Vinayaka. Sang Dewi bersabda Vinayaka harus dipuja pada hari keempat tiap pertengahan bulan. Orang yang melakukan pemujaan terhadap Vinayaka tidak akan mendapat kesulitan dalam mencapai apa yang diinginkannya. 


\section{Simbol-Simbol Ganesha}

Perwujudan Ganesha yang mengambil wujud fisik sebagai manusia berkepala gajah, juga dilengkapi dengan beberapa atribut yang secara keseluruhan memiliki pemaknaan atau kandungan nilai simbolis pada masing-masing atribut itu sendiri. Adapun simbol Ganesha dapat disimak pada gambar di bawah ini.

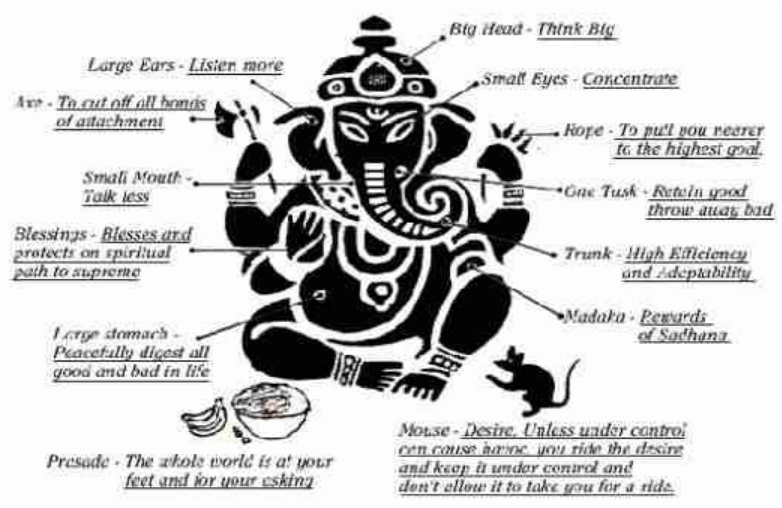

Gambar 1

Simbol-Simbol Ganesha

(Sumber: Joko, 2016)

Gambar 1 diatas merupakan perwujudan fisik dari Ganesha lengkap dengan infratsruktur atribut pelengkapnya. Adapun makna simbolik dari masing-masing simbol tersebut adalah sebagai berikut:

1. Ganapati digambarkan sebagai manusia berkepala gajah untuk menunjukkan kesatuan mahluk kecil (manusia) sebagai mikro kosmos dengan Yang Maha Agung sebagai makro kosmos. Gajah yang berkepala besar juga adalah simbol dari manusia yang seharusnya mempunyai volume otak yang besar dalam artian mempunyai kemampuan intelektual yang tinggi;

2. Telinga yang lebar adalah simbol laksana kebijaksanaan untuk banyak mendengarkan. Bagi para pelajar mendengarkan ucapan guru, bagi pemimpin mendengar pendapat bawahannya, bagi para cendekiawan mendengarkan kritik atau pendapat orang lain. Semuanya untuk didengar, dipikirkan, dan dipertimbangkan untuk mengambil langkah selanjutnya;

3. Berbelalai yang panjang, maknanya dapat memanfaatkan kemampuan yang ada untuk segala keperluan. Patung Ganesha ada yang belalainya menjulur ke kanan disebut Walamburi, dan ada yang menjulur kekiri, disebut Idamburi. Yang menjulur di tengah tidak diberi nama, karena dianggap sesuatu yang normal; 
4. Taring yang patah menyebabkan Ganesha juga disebut sebagai Ekadanta artinya yang bertaring satu. Taring yang patah adalah taring yang di sebelah kanan merupakan simbul pendukung kehidupan yang sejati (berwujud nyata) yang melenyapkan ilusi, sehingga kedua taring itu yang patah dan ynag utuh adalah simbul kesatuan antara yang berwujud dan yang tidak berwujud;

5. Ganesha berbadan gemuk dengan perut yang buncit, melambangkan semua manifestasi Hyang Widhi ada di dalam diri-Nya;

6. Ganesha mengendarai tikus (Musaka) simbol Atman (roh) yang menguasai semua bentuk perwujudan mahluk hidup;

7. Sikap tangan Ganesha yang memberikan anugerah (Varamudra) sebagai tanda Ia yang memenuhi segala keinginan. Tangan lain yang bersikap mengusir kecemasan (Abhayamudra) juga menolak segala halangan, bahaya, dan penderitaan. Sikap tangan yang membawa tali penjerat sebagai simbol penguasaan alam semesta oleh Hyang Widhi dan Ia juga mengatasi kehancuran (Moha);

8. Bertangan empat, simbol penguasaan Catur Veda, penguasaan empat unsur alam semesta, atau segala penjuru alam semesta;

9. Menduduki tengkorak (kapala) artinya sebagai keluarga Siva (Dewa Pralina) (Joko, 2016: th).

Berdasarkan rincian simbol Genesha di atas maka (Indrayasa, 2018: 90-91) berpendapat bahwa, kepala gajah dan empat lengan merupakan perwujudan utama dari Genesha. Setiap wujud Ganesha yang ada di dunia, umumnya selalu terkonstruk atas kepala gajah dan dilengkapi dengan empat lengan itu sendiri. Secara lebih lanjut, Indrayasa juga berpandangan bahwa Ganesha pada mulanya bernama Ekadanta (satu gading). Hal ini merujuk pada gadingnya yang utuh hanya berjumlah satu. Perut buncit Ganesha muncul sebagai ciri-ciri khusus pada kesenian patung sejak zaman dulu, yang ditaksir sejak periode Gupta (sekitar abad IV-VI). Penampilan ini amat penting, sebab penjelmaan Ganesha diambil dari Lambodara (perut buncit, atau, secara harfiah, perut bergelantungan) dan Mahodara (perut besar). Kedua nama tersebut adalah kata majemuk dalam bahasa Sanskerta, yang secara bersama mengartikan kondisi perut besar atau buncit. Kitab Brahmandapurana menegaskan bahwa, nama Lambodara pada Ganesha didasari oleh kepercayaan bahwa segala semesta pada masa lalu, sekarang, dan yang akan datang ada di dalam tubuh Ganesha itu sendiri. 


\section{Implementasi Mitologi Simbolik Ganesha Dalam Budaya Kontemporer Masyarakat Bali}

Kemajuan pola pikir serta cara pandang masyarakat Bali di era global, dapat memberikan berbagai pengaruh yang tidak saja terpaku dalam satu konteks atau aspek kehidupan. Kemajuan idiologi dan cara pandang masyarakat yang lebih banyak mengedepankan asas rasional, cenderung mengesampingkan berbagai hal yang dinilai masih bersifat kuno, mistis dan irasional. Sehingga, aspek-aspek kehidupan yang memang tidak dapat terlepas dari konteks irasional terlebih lagi masih diikat dengan pemikiran mistik, cenderung dipandang sebagai sesuatu yang tidak perlu mengalami perhatian dan penghormatan secara mengkhusus. Hal tersebut tentunya berpengaruh terhadap agama Hindu yang menggandeng berbagai cerita mitologis termasuk simbolisme tertentu yang bersifat mistis, sebagai media pengejawantahan kandungan nilai filosofis dalam Hindu itu sendiri. Widana (2018: 203) memandang permasalahan itu sebagai salah satu wujud dari memudarnya sikap kritis dan selektif dalam kehidupan budaya yang terjadi pada masyarakat Bali. Widana menegaskan bahwa, masyarakat Bali cenderung mudah menerima unsurunsur luar (asing). Kondisi ini diperkeruh lagi oleh sikap permisif tanpa filter yang menyebabkan masyarakat Bali rentan terpengaruh, terutama oleh hal negatif, destruktif dan kontraproduktif terhadap Bali dan nilai luhur di dalamnya.

Widana (2018: 204) juga memperjelas bahwa, besarnya sikap persmisif tanpa filter dari masyarakat Bali dapat dicermati mulai dari orientasi hidup yang sudah bergerak ke arah materi dan tampilan. Orientasi hidup yang mengarah pada materi dan penampilan, cenderung tidak mengedepankan rohani. Kebebasan berekspresi tidak mengacu pada aspek sakral dan rohani, namun selalu tertuju pada produktifitas ekonomi maupun peningkatan citra diri. Salah satu manifestasi dari hal tersebut adalah terjadinya kapitalisasi ikon teologi Ganesha. Realita dilapangan menunjukkan bahwa terdapat beberapa simbol-simbol suci keagamaan Hindu yang memiliki historikal mistis, cenderung dikemas kedalam berbagai bidang tertentu yang tidak lagi menjunjung kedudukan simbol sebagai sesuatu yang harus dihormati. Akan tetapi simbolisme itu sendiri sudah mulai diikat dengan pola pemikiran yang mengasumsikan bahwa simbol keagamaan layak dipergunakan sebagai sarana pelengkap demi mewujudkan tujuan atau citra pribadi. Kondisi tersebut juga berdampak terhadap ekistensi simbol dan mitologi Ganesha sebagai salah satu simbolisme mitologis dalam agama Hindu. Kandungan nilai filosofis serta pemaknaan yang terdapat dalam Ganesha tidak lagi hanya terpaku dipergunakan sebagai media pemujaan yang dikeramatkan, akan tetapi disisi lain juga telah dikombinasikan dengan beberapa kalsifikasi budaya masyarakat Bali yang telah diwarnai dengan unsur kontemporer atau kekinian. Secara 
umum, tujuan pokok penggunaan Ganesha dalam budaya kekinian masyarakat Bali, tidak hanya dipergunakan sebagai wujud penghormatan, namun juga dipergunakan untuk meningkatkan tujuan secara individual. Berdasarkan fenomena dilapangan dapat dikatakan bahwa penggunaan simbol dan mitologi Ganesha telah diimplementasikan kedalam beberapa klasifikasi aspek kehidupan antara lain dalam bidang arsitektur, estetika (kesenian), organisasi sosial, termasuk kehidupan ekonomi.

\section{Bidang Arsitektur}

Budaya arsitektur merupakan salah satu aspek yang selalu mengalami perkembangan dalam kehidupan masyarat Bali. Pembangunan infrastruktur fisik, secara bertahap tetap mengalami penyesuaian dengan perkembangan mode dan gaya kontruksi masa kini. Hal itu didorong pula oleh besarnya keinginan masyarakat untuk memiliki hunian yang sesuai dengan perkembangan terkini dalam lingkup arsitektur. Kondisi tersebut terkadang memiliki potensi untuk menggeser pola fikir dari para pelaku bisnis kontruksi di Bali, untuk menciptakan berbagai bentuk gaya dan mode arsitektur agar dapat mempertahankan minat dan daya beli masyarakat terhadap prodak kontruksi yang ditawarkan.

Lontar Asta Kosala-Kosali sebagai refrensi lokalistik dalam aktivitas pembangunan sekaligus sebagai pegangan bagi para Undagi di Bali, kini mulai ditinggalkan bahkan mengalami pergeseran dalam pola penerapannya. Realita dilapangan menunjukkan bahwa pembangunan yang terjadi di Bali saat ini, selalu berusaha untuk menyeret fakem dan tata kidah rancang bangun dalam Asta Kosala-Kosali yang kemudian digubah secara paksa sesuai dengan ruang lahan yang tersedia. Sehingga terjadi fenomena pembauran begitu juga ketidakjelasan antara pembangunan yang memang berdasarkan konsep Asta Kosala-Kosali dengan tata pembangunan modern yang sedikit mempergunakan konsep Asta Kosala-Kosali sebagai acuannya.

Fenomena diatas tidak saja terjadi dalam lingkup rancang bangun dalam sebuah ruang. Akan tetapi diikuti pula oleh pengejewantahan simbol-simbol keagaman Hindu tertentu, yang cenderung diimplementasikan sebagai sarana pelengkap guna menambah kesan serta nuansa keserasian dalam sebuah kontruksi ruangan. Disisi lain penempatan simbol keagamaan dalam sebuah tata bangunan, juga dimaksudkan hanya untuk mengisi beberapa bagian tempat yang terlihat sepi atau kosong.

Ganesha sebagai salah satu wujud simbolisme dalam keagamaan Hindu yang salah satunya dapat tertuang dalam bentuk kontruksi patung, juga sering dipergunakan sebagai sarana untuk melengkapi beberapa tempat dalam sebuah proses rancang bangun, ataupun 
kontruksi interior dalam sebuah ruangan. Unsur artistic, kegagahan, dan keindahan yang terdapat dalam kontruksi patung Ganesga, terkadang dapat menggugah para pelaku arsitektur serta desain ruang untuk menjadikan patung Ganesha sebagai salah satu sarana yang dipandang sangat tepat untuk memperindah beberapa bagian tempat dalam sebuah bangunan. Berdasarkan realita dilapangan dapat dikatakan bahwa penempatan patung Ganesha tidak lagi hanya diletakan sebagai salah satu Arca dalam Palinggih tertentu. Akan tetapi, juga difungsikan sebagai penghias pada taman, sudut-sudut tertentu disekitar rumah hunian, termasuk hiasan meja pada ruang tamu. Oleh sebab itu, sangat beralasan apabila Putrayasa dkk (2020: 5) berpandangan bahwa, pada zaman dahulu patung Ganesha difungsikan sebagai sarana pemujaan ditempatkan di pura atau tempat-tempat suci lainnya, namun saat ini banyak umat Hindu atau masyarakat Bali menempatkan patung Ganesha sebagai pelengkap keindahan arsitektur di berbagai jenis hunian atau bangunan.

Penggunaan Ganesha dalam arsitektur disesuaikan dengan ruang yang tersisa serta kepekaan estetis dari individu. Setiap konstruksi bangunan memiliki ketersediaan ruang yang berbeda. Kondisi ini menuntut para pelaku arsitektur untuk menyesuaikan bentuk dan ukuran Ganesha, agar sesuai dengan sisa ruang yang ada. Upaya memposisikan Ganesha dalam arsitektur, juga dipengaruhi oleh sudut pandang keindahan dari pemakaianya. Ganesha di tempatkan pada posisi khsusus, agar memperkuat unsur indah dari arsitektur yang dibangun. Meminjam pendapat Susanto (2011: 98) maka dapat dikatakan bahwa, internalisasi Ganesha dalam arsitektur dilakukan dengan dengan penyederhanaan, pembiasan, dan penggayaan, sehingga terjadi sebuah kesengajaan untuk kepentingan seni yang sering terkesan tidak sesuai dengan wujud atau figur aslinya.

Berdasarkan ulasan diatas maka dapat dikatakan bahwa keberadaan simbolisme Ganesha yang dalam hal ini tertuang dalam bentuk patung, tidak hanya dipergunakan atau diposisikan pada kontruksi bangunan Palinggih yang diamat keramat dan suci. Akan tetapi simbolisme Ganesha juga terseret dan difungsikan sebagai salah satu kontruksi agamais untuk melengkapi dan memperindah sebuah kontruksi ruang atau bangunan tertentu. Hal tersebut secara langsung dapat menjadi fenomena baru terkait dengan fungsionalisme dari simbol Ganesha, yang telah ikut bergabung dan dipadukan dalam kemajuan budaya arsitektur masyarakat Bali saat ini.

\section{Bidang Estetika (Seni)}

Penggunaan simbolisme Ganesha dalam kehidupan masyarakat Bali saat ini, tidak hanya terjadi dalam ranah perkembangan budaya arsitekur. Unsur artistic, kewibaan, dan 
keagungan yang terdapat dalam wujud fisik dari Ganesha kembali menjadi alasan mendasar bagi para seniman dan penikmat seni, untuk menuangkan simbolisme Ganesha dalam beberapa klasifikasi kesenian. Ketika peradaban masyarakat Hindu Bali masih berada dalam periode budaya agraris yang penuh dengan nuansa klasik, tradisionalis dan mistik, maka penghormatan serta implementasi Ganesha dalam media yang tergolong seni, hanya tertuang pada penyusunan Rerajahan sebagai pelengkap sebuah ritual upakara. Rerajahan itu sendiri dapat dikatakan sebagai salah satu bentuk seni lukis yang dituangkan dalam huruf termasuk gambar tertentu yang sarat akan makna mitologis, magis, dan sangat disakralkan.

Memasuki perdaban global saat ini, muncul pula kreatifitas baru dari para seniman khususnya seniman lukis, untuk melakukan upaya kolaborasi terhadap simbolisme Ganesha yang kini lebih banyak dituangkan dalam berbabagai media lukis. Realita dilapangan menunjukkan bahwa lukisan dengan objek Ganesha, tidak saja ditulis dalam media kanfas atau kain. Akan tetapi juga menjadi salah satu pilihan bagi pencinta Tatto untuk mengambil wujud Ganesha sebagai objek gambar (Tatto) pada tubuhnya (Putrayasa dkk, 2020: 5). Hal tersebut, mendorong munculnya seniman termasuk penikmat seni lukis Tatto yang menyediakan serta mempergunakan gambar Ganesha sebagai objek lukis.

Ganesha yang dipergunakan sebagai Tatto pada tubuh tidak dilukiskan secara lengkap. Kondisi ini juga didasari oleh minat estetis, ruang, serta kondisi kulit seseorang yang akan di Tatto. Meski tidak utuh, namun gambar Ganesha yang dipergunakan masih menunjukkan adanya beberapa atribut simbol sebagaimana berlaku dalam Hindu. Orang yang hendak melakukan Tatto dengan gambar Ganesha, cenderung memilih bagian kepala (kepala gajah dan mahkota) dari Ganesha itu sendiri. Bahkan, pada bagian tengah antara kedua alis dari gambar kepala Ganesha kerap dilengkapi dengan aksara suci Om Kara. Kepala Ganesha dipandang sebagai karakter dan ciri utama dari Genesha, sehingga selalu dipilih untuk gambar Tatto. Meminjam pendapat Kartika (2004:42-43), maka dapat dikatakan bahwa penggunaan gambar Ganesha dalam seni Tatto mempergunakan sistem deformasi atau perwujudan bentuk yang menekankan pada interpretasi karakter dengan mengubah bentuk objek dan diwujudkan hanya sebagian yang dianggap mewakili.

Penggunaan gambar Ganesha sebagai Tatto kerap melahirkan penilaian negatif dari pemerhati simbol Hindu. Gambar Ganesha yang dipergunakan pada tubuh sempat dipandang sebagai sebuah penodaan terhadap simbol suci. Oleh sebab itu, Widana (2018) mengkritik penggunaan Ganesha dalam seni Tatto melalui artikelnya yang berjudul "Tatto Ganesa, Tatu Bagi Umat Hindu". Secara emplisit, Widana berpendapat bahwa penggunaan Ganesha dalam seni Tatto sebagai salah satu masalah yang perlu mendapatkan perhatian. Hal ini tercetus dari 
kalimatnya yang menyatakan bahwa "penggunaan simbol Ganesha sebagai objek Tatto, tentu tidak bisa dipandang remeh". Widana juga memandang penggunaan Genesha dalam seni lukis tubuh adalah wujud dari komodifikasi yang berujung pada degradasi nilai kesucian dan pelecehan simbol suci Hindu. Hal ini dapat disimak melalui pendapatnya yang menerangkan bahwa “Dewa Genesha yang dipuja harus didegradasi nilai kesuciannya/kesakralannya, lalu dipindahkan sebagai objek Tatto pada media tubuh manusia (laki/perempuan), bahkan dengan penempatan pada posisi bagian tubuh yang tidak etis hingga lekuk organ vital dan sensual, tentu patut dipertanyakan bahkan wajib dipersoalkan tanggungjawab moralnya. Sebab penempatan sosok Dewa Genesha pada media tubuh merupakan komodifikasi yang berakibat terjadinya desakralisasi atau profanisasi, bahkan bisa dianggap sebagai tindakan pelecehan, penistaan atau penodaaan terhadap simbol suci Hindu".

Berdasarkan fenomena tersebut maka dapat dikatakan bahwa implementasi Ganesha pada budaya kesenian, khususnya seni lukis masa kini, lebih banyak difungsikan sebagai pusat inspirasi untuk menciptakan dimensi dan suasana baru terkait dengan bentuk, objek dan karakteristik sebuah karya lukis. Kesenian lukis dengan objek Ganesha juga dimaksudkan untuk meningkatkan daya tarik serta suasana spiritualis dari para penikmat kesenian lukis itu sendiri.

\section{Bidang Organisasi Sosial}

Keberadaan satuan budaya organisasi di Bali lebih banyak mendasarkan aktivitas dan pergerakannya sesuai dengan konsepsiologi dan ajaran dalam agama Hindu. Keluhuran makna yang terdapat dalam konsep agama Hindu, cenderung menjadi inspirasi bagi satuan kelompok organisasi untuk menciptakan berbagai program sesuai dengan makna filosofis dari ajaran Hindu itu sendiri. Terdapat beragam faham ajaran Hindu yang terakumulasi menjadi sebuah kontruksi simbol. Pada nantinya simbolisme tersebut akan difungsikan oleh beberapa satuan organisasi (Sekaa) yang ada, sebagai lambang atau label dari organisasi yang dimiliki.

Mitologi serta keluhuran simbolis dalam Ganesha juga sering dijadikan sebagai simbol dalam sebuah organisasi di Bali, baik organisasi kepemudaan (Sekha Teruna-Teruni), organisasi kebugaran jasmani, lembaga pendidikan perusahan-perusahan dan lain sebagainya (Putrayasa dkk, 2020: 5). Sebagaimana ulasan sebelumnya, maka tindakan, prinsip, program begitu juga cita-cita dan tujuan dari kelompok itu sendiri, diharapkan memiliki kesesuaian dengan sifat dan fungsi pokok dari setiap unsur simbolik yang terdapat dalam Ganesha. Akan tetapi dewasa ini kecenderungan pola fikir generasi muda begitu juga peradaban organisasi 
lebih mengarah kepada sikap egosentris diseratai pula dengan fanatisme berlebihan terhadap kelompok sendiri. Sehingga sangat riskan terjun kedalam lembah konflik dan perpecahan. Secara langsung hal itu juga berpengaruh terhadap pandangan atas Ganesha sebagai lambang yang menjadi panutan dalam kelompok organisasi itu sendiri.

Berdasarkan ulasan diatas maka dapat dianalisis bahwa, implementasi mitologi dan simbolisme Ganesha dalam budaya organisasi masyarakat Bali dewasa ini, lebih difungsikan sebagai objek spiritual yang mampu memberikan insprirasi serta patokan didalam pelaksanaan aktivitas dan tujuan pokok dari organisasi itu sendiri. Sifat umum dari Ganesha sebagai penghalang atau penumpas segala halangan, diresapi oleh satuan kelompok organisasi sebagai sebuah wujud kekuatan, semangat serta sikap kerja keras didalam menjalankan dan mewujudkan tujuan kelompok. Akan tetapi kecenderungan adanya belenggu fanatisme yang berujung pada konflik dan disintegrasi, berpotensi menyeret simbolisme Ganesha untuk menjadi pralambang negatif ditengah perpecahan yang terjadi.

\section{Bidang Ekonomi}

Perkembangan sektor ekonomi merupakan salah satu aspek yang memberikan pengaruh terbesar bagi kehidupan masyarakat Bali dari masa ke masa. Ketatnya persaingan pasar yang terjadi, mendorong masyarakat Bali untuk mampu berpikir kreatif agar memiliki peluang ikut serta dalam perbutan lahan finansal. Dalam kondisi tersebut, tidak tertutup kemungkian penyertaan simbolisme Ganesha sebagai salah satu label sebuah prodak, juga dipergunakan dalam dinamika pasar.

Berkaca dari fenomenologi yang terjadi dalam ranah pasar saat ini, maka dapat dikatakan bahwa penggunaan simbolisme Ganesha dalam sebuah kemasan produk mulai mengalami peningkatan. Hal tersebut banyak menyasar produk pasar yang lebih mengarah pada infrastruktur atau sarana prasarana upakara dalam agama Hindu seperti, label Dupa, Arak Tabuh dan sarana upakara lainnya. Disisi lain, penggunaan simbolisme Ganesha juga telah banyak dipergunakan dalam produk yang bukan tergolong sebagai sarana keagamaan seperti, motif sablon pada baju, tas dan produk lainnya (Putrayasa dkk, 2020: 5).

Penggunaan simbol Ganesha sebagai gambar atau sablon pada produk baju, sempat menggeliat. Hal ini tidak terlepas dari mode dan Fashion dari masyarakat yang gemar mengintegrasikan simbol Hindu dalam berbusana. Kondisi ini secara langsung menggiring simbol Ganesha sebagai salah satu gambar yang diintegrasikan dalam Fashion berbusana masyarakat Bali. Tingginya minat masyarakat menggunakan baju bergambar Ganesha, sempat mendatangkan keuntungan tersendiri bagi pengusaha busana atau sablon. Dilansir dari 
Koran Harian Bisnis Bali (26 Juni 2018, hal: 1) dinyatakan bahwa bisnis baju kaos gambar "Ongkara" dan "Genesha" sangat prospektif, sebab diminati oleh kalangan anak muda (Fashionista) dan dapat dikembangkan oleh sebagian besar pengusaha baju kaos.

Simbol Ganesha dalam budaya perekonomian saat ini, lebih condong dipergunakan untuk menarik minat dan daya beli masyarakat. Simbol Ganesha banyak dipergunakan sebagai Branding terhadap produk tertentu guna meningkatkan citra dan daya tarik terhadap produk yang ditawarkan. Hal tersebut secara mengkhusus akan lebih menyasar para kelompok spiritualis atau penekun agama dan kerohanian, sebagai konsumen sentral yang akan mempergunakan segala produk berlabel Ganesha yang ditawarkan. Mengacu pada pendapat Marx (dalam Turner, 2003: 115) maka fenomena ini merupakan wujud materialisme yang memandang bahwa dunia sosial dunia natural, tidak terlepas dari aktivitas praktis manusia. Aktivitas praktis manusia saat ini, lebih menitik beratkan pada materi dan membawa konsekuensi pada degradasi pada nilai nonmaterial (immaterial) dan atau spiritual. Hal inilah yang mendasari Widana (2018: 209) menilai kehidupan umat Hindu mengalami transformasi dari konep Bhakti menuju Bati. Kondisi tersebut, segaris dengan posisi ikon teologi Ganesha berada pada dua persimbangan yakni, penyertaan Ganesha dalam aktivitas Bhakti (sebagai kewajiban utama umat Hindu) dan perolehan Bati (keuntungan) sebagai tujuan kesejahteraan secara ekonomi.

Masuknya simbol Genesha dalam ruang ekonomi tidak terlepas dari perkembangan budaya pasar. Mengingat, budaya pasar dipandang sebagai salah satu ruang dalam mencapai kesejahtaraan secara finansial. Kesakralan simbol Ganesha pada masa agraris, berhasil digeser secara perlahan dengan masuknya budaya pasar, sehingga simbol Ganesha larut dalam perhelatan pasar itu sendiri. Hal ini segaris dengan proses menuju realitas budaya pasar menurut Abdullah (2016: 16) yakni pertama, masuknya pasar ke dalam masyarakat petani; kedua terjadinya integrasi dengan pasar; ketiga, terwujudnya ekspansi pasar.

Penggunaan simbolisme agama Hindu dalam sebuah prodak baik sarana keagamaan ataupun lainnya, sempat memunculkan adanya kontraversi dikalangan pemerhati agama. Simbolisme keagamaan yang seharusnya terus menerus mendapatkan penghormatan, disatu sisi terkadang dapat menjadi seonggok sampah yang tak berarti. Salah satu fenomena yang sempat memicu lahirnya kontradiksi tersebut adalah adanya limbah sampah dalam bentuk bekas kemasan produk Dupa, yang mempergunakan label bergambar Dewa-Dewa dalam Hindu (termasuk Ganesha). Hal tersebut sempat memicu adanya pandangan dan asumsi negatif terhadap agama Hindu, sebagai faham religi yang merangkul simbolisme filosofis tersebut. 


\section{PENUTUP}

Mitologi merupakan sebuah pengetahuan yang didalamnya mengupas begitu juga mendeskripsikan tentang ceritra bersifat irasional, bernuansa magis yang nantinya dipercaya keberadaannya sebagai sebuah pemahaman dan uraian filosofis pada sebuah kehidupan budaya masyarakat. Sedangkan simbol dapat diartikan sebagai simbol merupakan sesuatu yang dipergunakan untuk menunjukkan sesuatu dari sesuatu lainnya, baik berupa kata-kata (pesan Verbal), prilaku non Verbal serta objek yang maknanya telah dipahami serta disepakati secara bersama. Terdapat beragam sumber refrensi yang memberikan ulasan terkait dengan historis mitologi dari Ganesha. Beberapa kitab yang membahsan tentang eksistensi Ganesha seperti, Lingga Purana begitu juga kitab Matsya Purana dan Skanda Purana. Dari deskriopi masing-masing sumber tersebut secara umum keberadaan Ganesha memiliki keterkaitan dengan Deva Siva serta memiliki fungsi pokok sebagai penumpas segala rintangan negatif. Ganesha sebagai perwujudan manifestasi Tuhan dalam agama Hindu, memiliki pemaknaan serta konsepsiologi tersendiri. Makna tersebut nantinya akan dapat disimak dalam simbolsimbol pada atribut Ganesha seperti: senjata kapak dan bunga teratai yang dipegang, sikap tangan, dan atribut lainnya. Mitologi simbolik terkait dengan Ganesha telah meresap dalam berbagai lini kehidupan masyarakat, yang akhirnya menjadi objek dalam budaya kontemporer masyarakat Bali. implementasi Ganesha dapat disimak melalui beberapa klasifikasi budaya seperti arsitektur, estetika (seni), organisasi, termasuk dalam ranah ekonomi.

\section{DAFTAR PUSTAKA}

Abdullah, Irwan. 2006. Kontruksi dan Reproduksi Kebudayaan. Yogyakarta: Pustaka Pelajar.

Ardani, Ni Made. 2017. Nilai pendidikan agama hindu dalam penempatan patung ganesha di desa manistutu kecamatan melaya kabupaten jembrana. Jurnal Penelitian Agama Hindu, I (2), hlm. 371-375.

Bisnis Bali, 26 Juni 2018, halaman 1. “Bisnis Baju Kaos Gambar “Ongkara” Dan "Genesha” Prospektif".

Dharmayuda, I Made Suasthawa. 1995. Kebudayaan Bali: Pra Hindu, Masa Hindu dan Pasca Hindu. Denpasar; CV. Kayu Mas Agung.

Hartoko, Dick \& B.Rahmanto. 1998. Kamus Istilah Sastra. Yogyakarta: Kanisius.

Herusatoto, Budiono. 2000. Simbolisme dalam Budaya Jawa. Yogyakarta: Hanindita Graha Widia.

Indrayasa, Kadek Bayu. 2018. Patung Ganesha: suatu kajian teologi. Genta Hredaya, II (1), hlm. 88-94.

Joko, I Ketut. 2016. Memahami Mitology Dan Simbolis Dewa Ganesha: http//www.mantrahindu.com/2016/07/memahami-mitology-dan-simbolis-dewaGanesha/. (Diakses, 9/10/2017).

Kartika, Darsono Sony. 2004. Seni Rupa Modern. Bandung: Rekayasa Sain. 
Keramas, Dewa Made Tantra. 2008. Putra Sesana: Sistem Pendidikan Demi Ajegnya Bali. Surabaya: Paramita.

Kumbara, A.A Ngurah Anom. 2008. Ajeg Bali Dalam Pusaran Arus Globalisasi: Kritik Epistimis. Denpasar: Fakultas Sastra Universitas Udayana.

Mutakin, Anwar. 2006. Individu, Masyarakat, dan Perubahan Sosial. Bandung: Rosda.

Piliang, Yasraf Amir. 2011. Dunia yang Dilipat. Bandung: Penerbit Matahari.

Putra, I Nyoman Miarta. 2009. Mitos-Mitos Tanaman Upakara. Denpasar: PT Pustaka Manik Geni.

Putrayasa, I Nyoman; Karsana, I Putu; Sujana, I Made. 2020. Visualisasi imagine ganesha sebagai media komunikasi visual dalam seni patung. Stilistika, IX (1), hlm. 1-13.

Setyaningrum, Arie. 2002. Kajian budaya kontemporer. Jurnal Ilmu Sosial dan ILmu Politik, VI (2), hlm. 229-244.

Susanto, Mikke. 2011. Diksi Rupa. Yogyakarta: Dicti Art Lab Yogyakarta dan Jagat Art Space Bali.

Tim Penyusun. 2001. Kamus Besar Bahasa Indonesia Edisi Ke Tiga. Jakarta: Balai Pustaka.

Tim Penyusun. 2008. Kamus Besar Bahasa Indonesia. Jakarta: Balai Pustaka.

Titib, I Made. 2009. Teologi Dan Simbol-Simbol Dalam Agama Hindu. Surabaya: Paramita.

Turner, Bryan S. 2003. Agama Dan Teori Sosial. (Terj. Inyiak Ridwan Muzir). Yogyakarta: IRCiSoD.

Widana, I Gusti Ketut. 2018. Kapitalisasi Ikon Ganesha Dalam Industri Pariwisata di Ubud Bali, Prosiding Seminar Nasional Agama, Adat, Seni Dan Sejarah Di Zaman Milenial. Denpasar, 5 September, Universitas Hindu Indonesia.

Widana, I Gusti Ketut. 2018. Tatto Ganesa, Tatu Bagi Umat Hindu. https://www.unhi.ac.id/id/agama-budaya/detail-agama-budaya/TATTOGANESA,-TATU-BAGI-UMAT-HINDU (Diakses, 2 Agustus 2021). 